\title{
Testate amoebae (Protozoa: Testacealobosea and Testaceafilosea) as bioindicators in the Late Quaternary deposits of the Bykovsky Peninsula, Laptev Sea, Russia
}

\author{
Anatoly A. Bobrov ${ }^{\mathrm{a}}$, Andrei A. Andreev ${ }^{\mathrm{b}, *}$, Lutz Schirrmeister ${ }^{\mathrm{b}}$, Christine Siegert $^{\mathrm{b}}$ \\ ${ }^{a}$ Soil Department of Moscow State University, Vorobievy Gory, 119899 Moscow, Russia \\ ${ }^{\mathrm{b}}$ Alfred-Wegener-Institut for Polar and Marine Research, Research Department Potsdam, Telegrafenberg A43, 14473 Potsdam, Germany
}

Received 16 January 2003; accepted 5 February 2004

\begin{abstract}
Testate amoebae (Protozoa: Testacea) were studied in the Late Quaternary permafrost deposits in the Siberian Arctic (Bykovsky Peninsula of the Laptev Sea coast, $71^{\circ} 40^{\prime}-71^{\circ} 80^{\prime} \mathrm{N}$ and $129^{\circ}-129^{\circ} 30^{\prime} \mathrm{E}$ ). The Testacea associations studied reflect specific environmental conditions in paleocryosols, which were controlled by the local micro-relief as well as by regional climate conditions. In total, 86 species, varieties, and forms of testate amoebae were found in 38 Pleistocene and Holocene samples. The rhizopods indicate that soil conditions at ca. $53,000{ }^{14} \mathrm{C}$ years BP were probably rather similar to the modern cold and wet arctic tundra environment. More moisture and warmer soil conditions were relatively favorable for rhizopods ca. $45,300-43,000{ }^{14} \mathrm{C}$ years $\mathrm{BP}$, but it was significantly drier at about $42,000{ }^{14} \mathrm{C}$ years $\mathrm{BP}$. Drier and colder environmental conditions were also present about $39,300-35,000{ }^{14} \mathrm{C}$ years BP. The Late Pleistocene samples, radiocarbon dated to $33,000-12,000$ years BP, are characterized by a low species diversity and density indicating that this period may have been extremely cold and dry. This conjecture is also supported by the polymorphism of some species. Hydrophilic Difflugia species (mostly obligate hydrobiotes) are broadly represented in the studied Holocene samples. The species composition and density of rhizopods in the majority of Holocene samples suggest wet and relatively warm conditions. Changes in rhizopod assemblages during the last 53,000 years were not very dramatic, mostly consisting of rare species and changes in the dominant species complexes during the Pleistocene and Holocene. However, these changes were more drastic during the Pleistocene. They were probably at least partly responsible for the disappearance of some rare testacean species such as Argynnia sp.
\end{abstract}

(C) 2004 Elsevier B.V. All rights reserved.

Keywords: Testate amoebae; Palaeoecology; Permafrost; Holocene; Pleistocene; Siberian Arctic

* Corresponding author.

E-mail addresses: bobrov@bobrov.soils.msu.su (A.A. Bobrov), aandreev@awi-potsdam.de (A.A. Andreev), 1schirrmeister@awi-potsdam.de (L. Schirrmeister), csiegert@awi-potsdam.de (C. Siegert).

\section{Introduction}

Testate amoebae are a group of free-living protozoans that have an organic shell (testa). Some taxa from this group are covered with exogenous mineral material (xenosomes), plant detritus, or endogenous material (idiosomes), such as silica or, rarely, calcium phosphate 
plates. Their well-defined ecological preferences and the relatively good preservation of fossil shells in peats, lake sediments, and buried soils form the basis for the development of rhizopod analysis as a method for reconstruction of climate and environmental changes (Harnisch, 1927, 1948; Grospietsch, 1953; Schönborn, 1962; Meisterfeld, 1977; Tolonen, 1986).

Testate amoebae, being inherently aquatic, respond by restructuring their coenoses to environmental changes such as ground water table, moisture, $\mathrm{pH}$, content of biophilic elements ( $, \mathrm{P}, \mathrm{K}, \mathrm{Ca}, \mathrm{Mg}$ ), and organic matter. They can be classified into ecological groups according to their moisture (hygrophiles, hydrophiles) and $\mathrm{pH}$ requirements (acidophiles, calciophiles), and habitat preferences (sphagnophiles, soilliving, xerophiles). Their density in lake sediments, peat and soils can vary from a few hundred to tens of thousands of shells per $\mathrm{cm}^{3}$. The number of taxa in oligotrophic bogs can reach several tens of species.

The significance of rhizopod analysis for paleoecological studies is based on the fact that testate amoebae are permanently attached to the substrate. Their shells are normally destroyed if the sediments are redeposited. Therefore, they are often the only organisms that can directly indicate the paleoenvironmental conditions during sediment formation, unlike many other biological remains. Thus, the concept of paleocoenosis, one of the basic taphonomic concepts (Yanin, 1983), can be applied to the rhizopods.

In Russia, the importance of rhizopod analysis was raised after the Giliarov (1955) publication. However, only a few paleoecological studies using rhizopod analysis have been published since 1955 (e.g. Bobrov, 1995; Bobrov and Minaeva, 2000). The East Siberian Arctic has attracted the attention of paleoecologists, and some data about its modern and Late Quaternary biota (mostly concerning vegetation changes and mammoth fauna) are available (e.g. Yurtsev, 1966, 1981; Sher, 1997a,b; Andreev et al., 2002). However, there were no data concerning the evolution of soil protozoans in that area, although such study could provide unique information about biogeography, migration, paleoecology, environmental changes, and soil development in the region.

The study of modern rhizopods in high-latitude Arctic regions was initiated in the late 19th and early 20th centuries (Scourfield, 1897; Penard, 1903; Sandon, 1924) and was continued after a long interval
(Bonnet, 1965; Schönborn, 1966; Beyens and Chardez, 1986, Beyens et al., 1986a,b, 1991, 1992, 2000; Smith, 1987; Opravilova, 1989; Balik, 1994). Moss and lichen pads, soils, and small pools in eastern and western Greenland, northwestern Spitsbergen, Brabant Island, and some other Arctic areas were studied for rhizopods.

In the recent study concerning the rhizopod fauna of northeast Greenland (Trappeniers et al., 2002) special attention was paid to a quantitative evaluation of the relationships between a composition of testate amoebae soil assemblage and the ecological parameters (organic matter, moisture, etc.) of their habitats and communities.

Rhizopods collected near Murmansk and Vaygach Island in the Russian Arctic were studied by Averintsev and Levander (Beyens et al., 2000). The rhizopods are not numerous in the moss and aquatic biotopes of the coastal areas of the Barents and Kara Seas; only 45 species, varieties and forms have been found there (Beyens et al., 2000).

Recent studies show that the density and biodiversity of testaceans in the modern high-latitude Arctic is reduced with lower average summer temperatures (harsher climate conditions) and some species respond to lower temperatures by reducing the size of their shells (Smith, 1988). In the paleoecological studies, rhizopod analysis has been used mainly to investigate the evolution of oligotrophic bogs in the boreal zone. One notable exception is a study of bog sediments from the Spitsbergen (Beyens and Chardez, 1987). The researchers were able to reconstruct changes in the water regime during the last 1200 years. Thus, rhizopods are unique bioindicators that can be used as a proxy for reconstructions of paleoenvironmental changes in the high Arctic.

In this paper we present the first results of testate amoebae investigations in the Late Pleistocene-Holocene sediments and recent soils from the East Siberian Arctic (Bykovsky Peninsula, Laptev Sea coast). The studies took place within the GermanRussian scientific cooperation program "System Laptev Sea 2000".

\section{Study area}

The coastal section "Mamontovy Khayata" $\left(71^{\circ} 40^{\prime}-71^{\circ} 80^{\prime} \mathrm{N}\right.$ and $\left.129^{\circ}-129^{\circ} 30^{\prime} \mathrm{E}\right)$ is located 


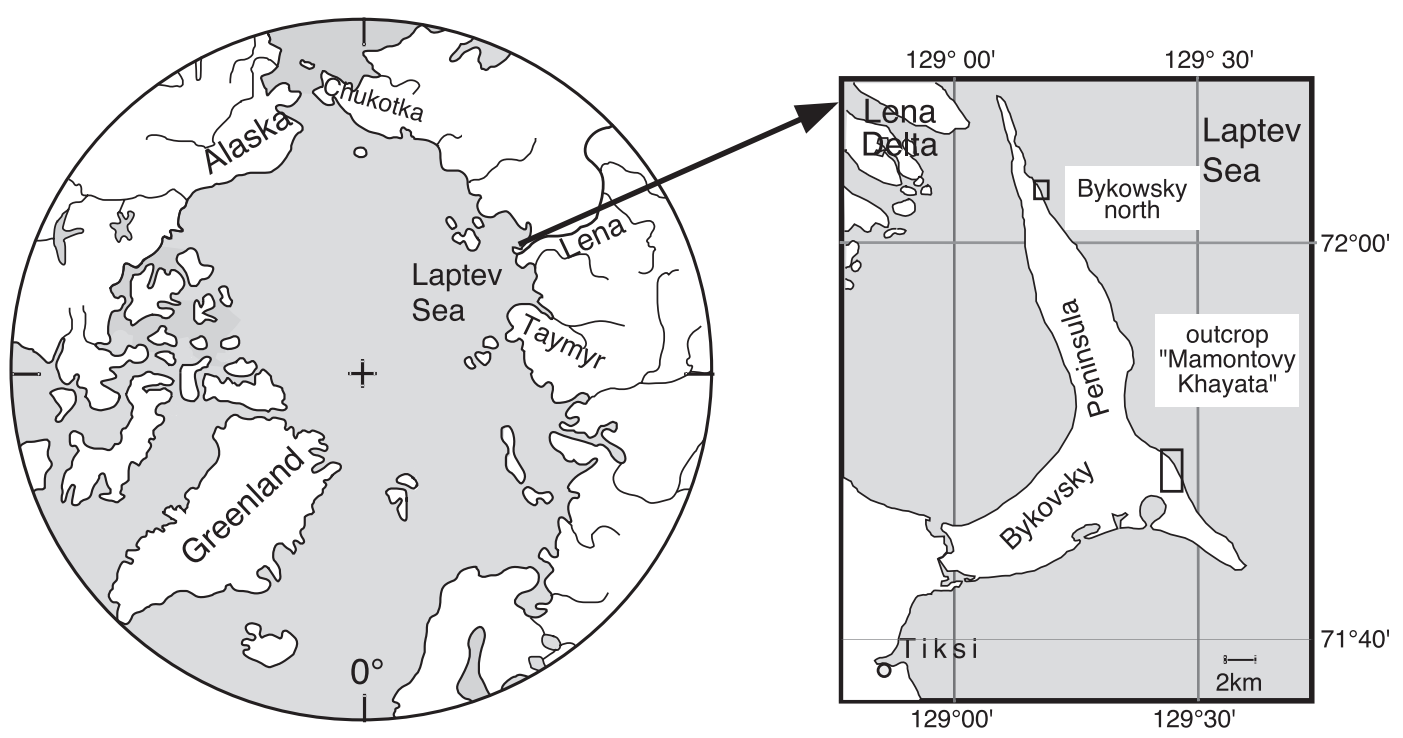

Fig. 1. Map of the Arctic and the Tiksi region showing the location of the studied sites.

on the Bykovsky Peninsula of the Laptev Sea coast, southeast of Lena Delta (Fig. 1). Coastal and thermoerosion has created high coastal cliffs (up to $40 \mathrm{~m}$ a.s.1.), trending NNW-SSE, and extending intermittently for about $2 \mathrm{~km}$. The studied permafrost sequences (Fig. 2) consist of syngenetically frozen deposits of the so-called Ice Complex, comprising deposits of alluvial plains in front of mountain ranges formed during the Late Pleistocene. These deposits contain large amounts of ground ice in the form of massive polygonal ice wedges and segregated ice within the sediment. Cryoturbation features up to $0.5-1 \mathrm{~m}$ high disturb the deposits, especially paleosols. The Holocene sequences studied consist of deposits formed by thermokarst processes and accumulated in thermokarst depressions and thermoerosional valleys. For detailed sedimentological and cryolithological descriptions of the sections studied see Siegert et al.

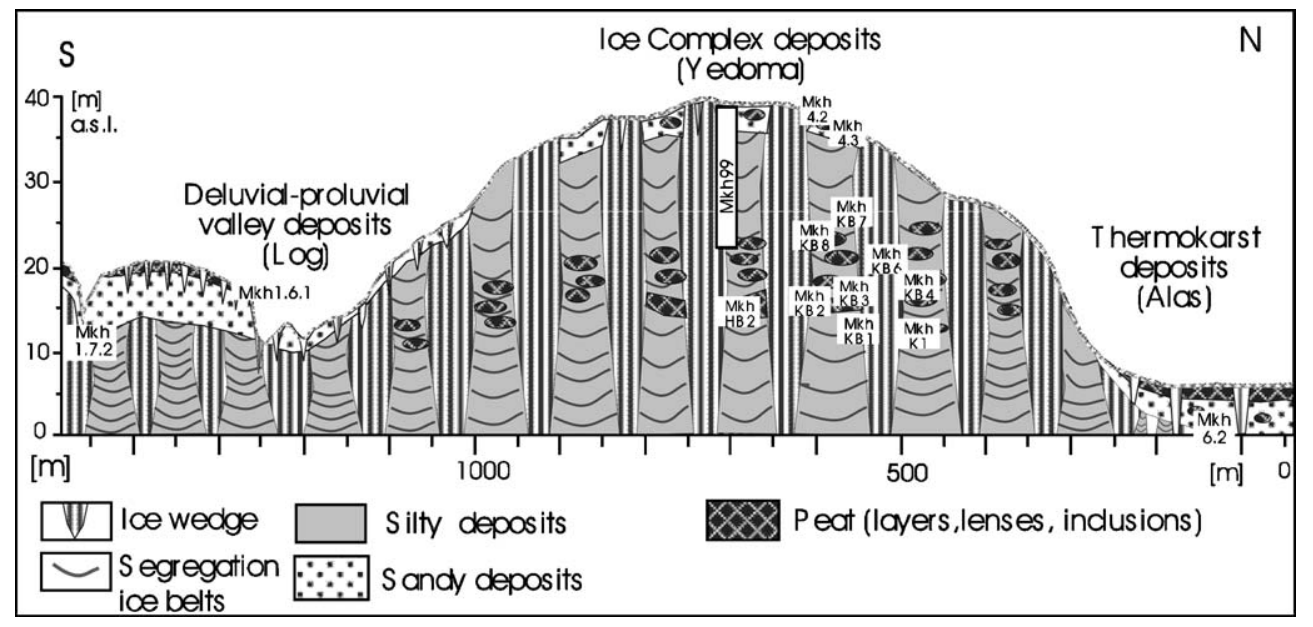

Fig. 2. Generalized section of Late Quaternary sediments of the Mamontovy Khayata (Bykovsky Peninsula) outcrop with the positions of the investigated sections. 
Table 1

List of testate amoebae species in the Pleistocene and Holocene deposits

\begin{tabular}{|c|c|c|c|}
\hline \multirow[t]{2}{*}{ Species } & \multicolumn{2}{|c|}{ Frequency $(\%)$} & \multirow{2}{*}{$\begin{array}{l}\text { Ecological } \\
\text { characteristics }\end{array}$} \\
\hline & Pleistocene & Holocene & \\
\hline Arcella arenaria Greef & 5.3 & 21.1 & M \\
\hline $\begin{array}{l}\text { A. arenaria v. compressa } \\
\text { Chardez }\end{array}$ & 21.1 & 21.1 & M \\
\hline $\begin{array}{l}\text { A. rotundata v. aplanata } \\
\text { Deflandre }\end{array}$ & 0.0 & 5.3 & WM \\
\hline A. sp. & 0.0 & 5.3 & - \\
\hline $\begin{array}{l}\text { Centropyxis aculeata } \\
\text { (Ehrenberg) Stein }\end{array}$ & 5.3 & 0.0 & W \\
\hline C. aerophila Deflandre & 26.3 & 89.5 & M \\
\hline $\begin{array}{l}\text { C. aerophila v. sphagnicola } \\
\text { Deflandre }\end{array}$ & 0.0 & 5.3 & $\mathrm{SpM}$ \\
\hline $\begin{array}{l}\text { C. aerophila } \text { v. grandis } \\
\text { Stepanek }\end{array}$ & 0.0 & 15.8 & W \\
\hline $\begin{array}{l}\text { C. aerophila v. minuta } \\
\text { Chardez }\end{array}$ & 10.5 & 5.3 & WMS \\
\hline $\begin{array}{l}\text { C. cassis (Wallich) } \\
\text { Deflandre }\end{array}$ & 47.4 & 84.2 & ShSBM \\
\hline $\begin{array}{l}\text { C. cassis v. grandis } \\
\text { Chibisova }\end{array}$ & 0.0 & 5.3 & W \\
\hline $\begin{array}{l}\text { C. constricta (Ehrenberg) } \\
\text { Penard }\end{array}$ & 47.4 & 68.4 & WS \\
\hline $\begin{array}{l}\text { C. constricta v. minima } \\
\text { Decloitre }\end{array}$ & 47.4 & 47.4 & W \\
\hline $\begin{array}{l}\text { C. ecornis (Ehrenberg) } \\
\text { Leidy }\end{array}$ & 0.0 & 21.1 & W \\
\hline $\begin{array}{l}\text { C. elongata (Penard) } \\
\text { Thomas }\end{array}$ & 0.0 & 36.8 & MS \\
\hline C. gibba Deflandre & 0.0 & 15.8 & $\mathrm{BM}$ \\
\hline $\begin{array}{l}\text { C. kolkwitzi Schönborn } \\
\text { f. A (grandis) }\end{array}$ & 5.3 & 0.0 & W \\
\hline C. laevigata Penard c.f. & 10.5 & 0.0 & WBMS \\
\hline C. orbicularis Deflandre & 42.1 & 42.1 & WShM \\
\hline $\begin{array}{l}\text { C. plagiostoma Bonnet, } \\
\text { Thomas }\end{array}$ & 26.3 & 78.9 & $\mathrm{~S}$ \\
\hline $\begin{array}{l}\text { C. plagiostoma } \mathrm{f} . A \\
\text { (major) }\end{array}$ & 63.2 & 52.6 & $\mathrm{~S}$ \\
\hline $\begin{array}{l}\text { C. plagiostoma f. } B \\
\text { (minor) }\end{array}$ & 47.4 & 21.1 & $\mathrm{~S}$ \\
\hline $\begin{array}{l}\text { C. platystoma (Penard) } \\
\text { Deflandre }\end{array}$ & 10.5 & 47.4 & SWM \\
\hline $\begin{array}{l}\text { C. sylvatica (Deflandre) } \\
\text { Thomas }\end{array}$ & 47.4 & 63.2 & WShM \\
\hline $\begin{array}{l}\text { C. sylvatica } \mathrm{v} \text {. } \\
\text { microstoma } \text { Bonnet }\end{array}$ & 5.3 & 0.0 & $\mathrm{~S}$ \\
\hline $\begin{array}{l}\text { C. sylvatica v. minor } \\
\text { Bonnet, Thomas }\end{array}$ & 36.8 & 26.3 & ShS \\
\hline C. sylvatica f. A (major) & 0.0 & 5.3 & - \\
\hline C. sp. 1 & 0.0 & 10.5 & - \\
\hline C. sp. 2 & 0.0 & 52.6 & - \\
\hline $\begin{array}{l}\text { Cyclopyxis eurystoma } \\
\text { Deflandre }\end{array}$ & 21.1 & 15.8 & WSh \\
\hline
\end{tabular}

Table 1 (continued)

\begin{tabular}{|c|c|c|c|}
\hline \multirow[t]{2}{*}{ Species } & \multicolumn{2}{|c|}{ Frequency $(\%)$} & \multirow{2}{*}{$\begin{array}{l}\text { Ecological } \\
\text { characteristics }\end{array}$} \\
\hline & Pleistocene & Holocene & \\
\hline $\begin{array}{l}\text { C. eurystoma } \mathrm{v} \text {. } \\
\text { parvula } \text { Bonnet, } \\
\text { Thomas }\end{array}$ & 31.6 & 63.2 & $\mathrm{~S}$ \\
\hline C. kahli Deflandre & 21.1 & 36.8 & WM \\
\hline C. puteus Thomas & 5.3 & 0.0 & $\mathrm{~S}$ \\
\hline $\begin{array}{l}\text { Plagiopyxis bathystoma } \\
\text { Bonnet }\end{array}$ & 0.0 & 10.5 & - \\
\hline P. callida Penard & 15.8 & 0.0 & WShMS \\
\hline $\begin{array}{l}\text { P. callida f. grandis } \\
\text { Thomas }\end{array}$ & 5.3 & 0.0 & BMS \\
\hline P. declivis Thomas & 26.3 & 0.0 & ShS \\
\hline $\begin{array}{l}\text { P. minuta v. oblonga } \\
\text { Bonnet }\end{array}$ & 5.3 & 0.0 & $\mathrm{~S}$ \\
\hline P. penardi Thomas & 5.3 & 5.3 & WS \\
\hline$P$. sp. & 5.3 & 0.0 & - \\
\hline $\begin{array}{l}\text { Heleopera petricola } \\
\text { Leidy }\end{array}$ & 10.5 & 10.5 & WS \\
\hline Argynnia sp. & 15.8 & 0.0 & - \\
\hline $\begin{array}{l}\text { Nebela bigibbosa } \\
\quad \text { Penard }\end{array}$ & 0.0 & 15.8 & WBM \\
\hline N. lageniformis Penard & 0.0 & 10.5 & ShM \\
\hline N. parvula Cash & 0.0 & 105 & ShM \\
\hline $\begin{array}{l}\text { N. tincta (Leidy) } \\
\text { Awerintzew }\end{array}$ & 0.0 & 5.3 & ShM \\
\hline $\begin{array}{l}\text { Schoenbornia humicola } \\
\text { (Schönborn) Decloitre }\end{array}$ & 21.1 & 0.0 & $\mathrm{~S}$ \\
\hline $\begin{array}{l}\text { Difflugia ampululla } \\
\text { Playfair }\end{array}$ & 0.0 & 5.3 & $\mathrm{~W}$ \\
\hline $\begin{array}{l}\text { D. angulostoma } \\
\text { Gauthier-Lievre and } \\
\text { Thomas }\end{array}$ & 0.0 & 15.8 & $\mathrm{~W}$ \\
\hline D. brevicola Cash & 0.0 & 10.5 & $\mathrm{~W}$ \\
\hline D. decloitrei Godeanu & 5.3 & 15.8 & W \\
\hline D. difficilis Thomas & 0.0 & 10.5 & W \\
\hline D. globularis Wallich & 0.0 & 15.8 & W \\
\hline D. globulosa Dujardin & 0.0 & 52.6 & W \\
\hline $\begin{array}{l}\text { D. globulus (Ehrenberg) } \\
\text { Hopkinson }\end{array}$ & 10.5 & 63.2 & WSh \\
\hline D. lacustris (Penard) & 0.0 & 10.5 & W \\
\hline D. litophila Penard & 0.0 & 5.3 & W \\
\hline D. lucida Penard & 5.3 & 0.0 & WSh \\
\hline D. mica Frenzel & 0.0 & 15.8 & W \\
\hline D. minuta Rampi & 0.0 & 21.1 & $\mathrm{Sh}$ \\
\hline D. oblonga Ehrenberg & 0.0 & 21.1 & W \\
\hline $\begin{array}{l}\text { D. oblonga } \text { v. longilollis } \\
\text { Gassowsky }\end{array}$ & 0.0 & 5.3 & W \\
\hline $\begin{array}{l}\text { D. oblonga f. A } \\
(160 \mathrm{mkm})\end{array}$ & 0.0 & 10.5 & W \\
\hline D. molesta Penard & 0.0 & 5.3 & $\mathrm{~W}$ \\
\hline D. penardi Hopkinson & 0.0 & 5.3 & W \\
\hline D. pristis Penard & 5.3 & 5.3 & W \\
\hline D. pulex Penard & 0.0 & 15.8 & W \\
\hline
\end{tabular}


Table 1 (continued)

\begin{tabular}{|c|c|c|c|}
\hline \multirow[t]{2}{*}{ Species } & \multicolumn{2}{|c|}{ Frequency $(\%)$} & \multirow{2}{*}{$\begin{array}{l}\text { Ecological } \\
\text { characteristics }\end{array}$} \\
\hline & Pleistocene & Holocene & \\
\hline Lagenodifflugia $\mathrm{sp}$. & 0.0 & 5.3 & - \\
\hline $\begin{array}{l}\text { Phryganella acropodia } \\
\text { (Hertwig et Lesser) } \\
\text { Hopkinson }\end{array}$ & 10.5 & 10.5 & WMS \\
\hline $\begin{array}{l}\text { Ph. acropodia v. } \\
\text { australica } \\
\text { Playfair c.f. }\end{array}$ & 0.0 & 31.6 & $\mathrm{~W}$ \\
\hline $\begin{array}{l}\text { Assulina muscorum } \\
\text { Greef }\end{array}$ & 0.0 & 10.5 & M \\
\hline $\begin{array}{l}\text { Valkanovia delicatula } \\
\text { (Valkanov) }\end{array}$ & 0.0 & 15.8 & M \\
\hline Cyphoderia sp. & 0.0 & 5.3 & $\mathrm{~W}$ \\
\hline $\begin{array}{l}\text { Euglypha anadonta } \\
\text { Bonnet }\end{array}$ & 0.0 & 10.5 & $\mathrm{~S}$ \\
\hline $\begin{array}{l}\text { E. ciliata (Ehrenberg) } \\
\text { Wailes }\end{array}$ & 0.0 & 5.3 & WShM \\
\hline $\begin{array}{l}\text { E. ciliata f. glabra } \\
\text { Wailes }\end{array}$ & 5.3 & 5.3 & WShMS \\
\hline E. compressa Carter & 0.0 & 10.5 & $\mathrm{ShM}$ \\
\hline $\begin{array}{l}\text { E. laevis (Ehrenberg) } \\
\text { Perty }\end{array}$ & 0.0 & 15.8 & SWBM \\
\hline $\begin{array}{l}\text { E. strigosa (Ehrenberg) } \\
\text { Leidy }\end{array}$ & 0.0 & 10.5 & ShM \\
\hline E. tuberculata Dujardin & 0.0 & 10.5 & WBM \\
\hline E. sp. & 5.3 & 15.8 & - \\
\hline $\begin{array}{l}\text { Corythion dubium } \\
\text { Taranek }\end{array}$ & 0.0 & 10.5 & WShM \\
\hline $\begin{array}{l}\text { Trinema complanatum } \\
\text { Penard }\end{array}$ & 0.0 & 10.5 & ShMS \\
\hline $\begin{array}{l}\text { T. enchelys (Ehrenberg) } \\
\text { Leidy }\end{array}$ & 0.0 & 10.5 & WShM \\
\hline T. lineare Penard & 5.3 & 15.8 & WShMS \\
\hline $\begin{array}{l}\text { Pseudodifflugia } \\
\text { gracilis } \\
\text { Schlumberger }\end{array}$ & 5.3 & 0.0 & $\mathrm{~W}$ \\
\hline
\end{tabular}

$\overline{\mathrm{M} \text { - green mosses, Sh-Sphagnum, W-water, B-bog; S- soil. }}$ Ecological characteristics are according Chardez (1965).

(1999, 2002), Sher et al. (2000), and Schirrmeister et al. (2001, 2002a,b).

The modern climate of the area is characterized by long (8 month), severe winters, and short, cold summers with about $9{ }^{\circ} \mathrm{C}$ for mean July temperatures, -32 to $-34{ }^{\circ} \mathrm{C}$ for mean January temperatures, and about 200 to $300 \mathrm{~mm}$ for annual precipitation (Atlas Arktiki, 1985).

Soils in the area are mainly tundra-gley and peatygley (histosols and inceptisols) with an active-layer thickness of about 30-40 cm (Atlas Arktiki, 1985).
This area belongs to the zone of northern tundra. Moss-grass low shrub tundra dominates the vegetation, with vascular plant species such as Betula exilis, Dryas punctata, Salix pulchra, Cassiope tetragona, Oxyria digyna, Alopecurus alpinus, Poa arctica, Carex ensifolia, C. rotundifolia, and Eriophorum medium. Mosses such as Aulacomnium turgidum, Hylocomium alaskanum, Drepanocladus iniciatus, and Calliergon sarmentosum, and lichens such as Alectoria ochroleuca, Cetraria cuculliata, and $C$. hiascus are also present (Atlas Arktiki, 1985).

\section{Methods}

The Mamontovy Khayata site was investigated during 1998-2001. It was not possible to collect samples from one continuous section. The samples were taken from baydzharakhs (thermokarst mounds), in which frozen deposits remain after melting of surrounding ice wedges. After the cleaning, sections were described and sampled for testate amoebae, pollen, macrofossil, sedimentological analyses, and radiocarbon dating. The sections studied are presented in Fig. 2.

About 70 AMS and 20 conventional radiocarbon age determinations of plant remains were used for a chronological differentiation of the deposits (Schirrmeister et al., 2002a). They show that deposits were continuously accumulated during the last 60,000 years. For the age estimation of non-dated samples we use an age/altitude relation model according Schirrmeister et al. (2002b).

Testate amoebae were extracted from $1 \mathrm{~g}$ of the sediments with a $500 \mu \mathrm{m}$ sieve and than concentrated with a centrifuge. A drop of the concentrate was placed on a slide, and then glycerol was added. Normally, five subsamples were examined at 200$400 \times$ magnification on the light microscope. The electron microscopes of the Institute for Zoo and Wildlife Research, Berlin and the Institute of Evolution and Ecology of the Russian Academy of Science, Moscow were also used for the more exact identification of a number of shell remains.

The so-called detrended correspondent analyses, which appear to be very useful for the ordination of environmental microhabitat variables of testate amoebas (e.g. Bobrov et al., 1999) have also been used in 
Table 2

List of studied samples

\begin{tabular}{llll}
\hline $\begin{array}{l}\text { Sample ID, } \\
\text { elevation (a.s.1) }\end{array}$ & $\begin{array}{l}\text { Type of } \\
\text { sediment }\end{array}$ & $\begin{array}{l}\text { Age, }{ }^{14} \mathrm{C} \\
\text { years BP }\end{array}$ & Rhizopod assemblages and their ecological interpretation \\
\hline 1. B-S7, 1 m & $\begin{array}{l}\text { peat inclusion } \\
\text { in ice-rich silt }\end{array}$ & $\begin{array}{l}53,020+ \\
2670 /-2000\end{array}$ & $\begin{array}{l}\text { 15 species, varieties and forms mostly from Centropyxis, Cyclopyxis, and } \\
\text { Plagiopyxis genera (eurytopic-soil inhabitants) are comparable to the species } \\
\text { complex from modern soils in the area. The presence of the hygrophilic P. callida and } \\
\text { Difflugia pristis suggests a hydromorphic soil. }\end{array}$
\end{tabular}
$\begin{array}{ll}\text { 2. MkhK1-S5, peaty soil } & 45,300+ \\ 10.5 \mathrm{~m} . & 1200 /-105\end{array}$

$\begin{array}{lll}\text { 3. MkhKB2-S2, } & \text { cryoturbated } & 44,280+ \\ 14.8 \mathrm{~m} & \begin{array}{l}\text { peaty soil with } \\ \text { shrub remains }\end{array} & 1320 /-1130 \\ & \end{array}$

\begin{tabular}{|c|c|c|}
\hline $\begin{array}{l}\text { 4. MkhHB2-S4, } \\
15.05 \mathrm{~m}\end{array}$ & $\begin{array}{l}\text { sandy moss } \\
\text { peat }\end{array}$ & $>44,980$ \\
\hline $\begin{array}{l}\text { 5. MkhHB2-S10, } \\
15.75 \mathrm{~m}\end{array}$ & $\begin{array}{l}\text { sandy moss } \\
\text { peat }\end{array}$ & $>41,830$ \\
\hline
\end{tabular}
6. MkhKB3-S1, peaty soil 39,320+ $10.8 \mathrm{~m} \quad 600 /-560$

7. MkhKB4-S2, silty soil ca. 35,000 $14.9 \mathrm{~m}$

8. MkhKB8-S3, $18.5 \mathrm{~m}$

$\begin{array}{ll}\text { cryoturbated } & 35,050+ \\ \text { peaty soil } & 390 /-370\end{array}$

9. MkhKB8-S4, peaty-clayey $\quad 34,800+$ $17.5 \mathrm{~m}$
13 taxa, mostly eurybiotic and soil Centropyxis but also an aquatic-moss inhabitant, Difflugia lucida; a coarse-humus hydromorphic Argynnia sp. and a calceophilic C. plagiostoma. Schoenbornia humicola (coarse-humus hydromorphic habitant) indicates raw and acid humus origin of the organic matter. Presence of pedobiotic Plagiopyxis species also confirms the soil humus origin of the organic matter. Cyclopyxis puteus, an alluvial and sandy soil species (Decloitre, 1977), has been found in high-latitude Arctic for the first time. This species is absent in the studied Holocene and recent samples. Species complex suggests a slightly acidic or near-neutral $\mathrm{pH}$ and a hydromorphic character of the soil. Temperatures seem to have been quite favorable, as species are now distributed mainly in the forest zone, are well represented.

15 taxa, mainly soil and eurybiotic Centropyxis and soil Plagiopyxis. The calceophilic $C$. plagiostoma represented by two size groups previously found only in forest soils with a soft humus (Foissner and Korganova, 1995). The presence of Schoenbornia humicola indicates a coarse-humus origin of the organic matter. Hydrophilic Difflugia globulosa and Argynnia sp. point to high water level in the habitat. C. laevigata has not been previously recorded north of $70^{\circ} \mathrm{N}$, although broadly present in the moss pads of West Greenland, at $66-67^{\circ} \mathrm{N}$ (Beyens et al., 1992). The ecological conditions were similar to those reconstructed from the Mkh-K1-5 sample.

6 species in the paleocoenosis. The hygrophilic Arcella arenaria v. compressa and Centropyxis platystoma indicate a near-surface water table and mesotrophic nutrient supply. This is also supported by the presence of the calceophilic C. plagiostoma (major and minor forms).

9 species in the rhizopod assemblage. The site was characterized by high water level, as eurybiotic species are accompanied by the hydrophilic Difflugia decloitrei and the hygrophilic Argynnia sp. Numerous diatom shells and ostracods also support the hydromorphic character of the habitat. The findings of eudominant Cyclopyxis kahli, not previously found in the high-latitude Arctic, is an indirect indication of a soil environment warmer than at present.

10 species. Dominant complex is represented by eurytopic and soil species (e.g. Centropyxis sylvatica and C. plagiostoma). Soil species are not numerous, the polymorphic $C$. plagiostoma is represented by the major form. This, together with findings of hydrophilic species of Arcella and Difflugia, indicates wet conditions and rather mesophilic nutrient supply.

High species diversity (15 taxa), high density of coarse-humus taxa, presence of species (Schoenbornia humicola, Euglypha ciliata, Trinema lineare) actively using soil water silica to build their shells. Soil rhizopods are represented by polymorphic Centropyxis plagiostoma. Presence of all subspecies of eurybiotic C. sylvatica might indicate highly heterogenic habitats or seasonal changes in ecological variables (Bobrov, 1999). Soil moisture conditions were probably optimal as indicated by the presence of hygrophilic $C$. assis and C. orbicularis. Climate was rather favorable. Few remains of three species. Very low density and poor species diversity may indicate low temperatures. Presence of Centropyxis platystoma, an aquatic-moss habitant (Chardez, 1965), indicates wet conditions. High density of ostracods also suggests an aquatic habitat.

10 rhizopod taxa, representing mainly eurybiotic and soil species. The presence of Centropyxis cassis, C. constricta and Plagiopyxis callida indicates a high water level. 
Table 2 (continued)

\begin{tabular}{|c|c|c|c|}
\hline $\begin{array}{l}\text { Sample ID, } \\
\text { elevation (a.s.l) }\end{array}$ & $\begin{array}{l}\text { Type of } \\
\text { sediment }\end{array}$ & $\begin{array}{l}\text { Age, }{ }^{14} \mathrm{C} \\
\text { years BP }\end{array}$ & Rhizopod assemblages and their ecological interpretation \\
\hline $\begin{array}{l}\text { 10. MkhKB6-S10, } \\
19.6 \mathrm{~m}\end{array}$ & $\begin{array}{l}\text { peaty-clayey } \\
\text { soil }\end{array}$ & ca. 34,000 & $\begin{array}{l}\text { Few remains of the } 3 \text { eurybiotic Centropyxis species and the calceophilic } C \text {. } \\
\text { plagiostoma. The sample represents a humus-accumulating horizon of buried soil, } \\
\text { covered by sparse vegetation. }\end{array}$ \\
\hline $\begin{array}{l}\text { 11. MkhKB7-S2, } \\
20.7 \mathrm{~m}\end{array}$ & clayey soil & ca. 33,000 & $\begin{array}{l}\text { Environment was similar to the peaty-clayey soil of Mkh-KB6-10, but the presence } \\
\text { of the hygro- and sphagnophilic Heleopera petricola, as well as the high density of } \\
\text { diatom shells, indicate wetter conditions. }\end{array}$ \\
\hline $\begin{array}{l}\text { 12. MkhKB7-S3, } \\
20.7 \mathrm{~m}\end{array}$ & $\begin{array}{l}\text { peaty inclusion } \\
\text { into the soil }\end{array}$ & $\begin{array}{l}33,450+ \\
260 /-250\end{array}$ & $\begin{array}{l}\text { Rhizopod complex ( } 13 \text { species) is ecologically similar to that in of Mkh-KB2-2 } \\
\text { (cryoturbated soil, ca. } 44,000 \text { years BP) but moisture regime appears to have been } \\
\text { more hydromorphic and the habitat was wetter, as indicated by the presence of } \\
\text { hydrophilic species of the Arcella and Difflugia genera. }\end{array}$ \\
\hline $\begin{array}{l}\text { 13-18. Mkh99 } \\
\text { profile, } \\
\text { S2-S } 24 \\
22.5-37 \mathrm{~m}\end{array}$ & $\begin{array}{l}\text { silty ice-rich } \\
\text { deposits }\end{array}$ & $\begin{array}{l}\text { from } 25,570+ \\
170 /-160 \\
\text { to } 13,920 \pm 100\end{array}$ & $\begin{array}{l}\text { Sporadic findings of rhizopods and very low species diversity ( } 2-6 \text { species). No } \\
\text { sphagnophilic or hydrophilic species. The assemblages are dominated by eurybiotic } \\
\text { species, although pedobiotic Plagiopyxis declivis was also observed. Many species } \\
\text { are represented in minor form, i.e. Centropyxis aerophila v. minor, C. constricta v. } \\
\text { minor, C. plagiostoma f. B (minor), C. sylvatica v. minor. Probably, the minor forms } \\
\text { reflect a survival strategy to lower temperatures (Smith, 1988) or to lower availability } \\
\text { of water in the soil (Chardez and Leclercq, 1963; Heal, 1963; Bobrov et al., 1999). } \\
\text { Rhizopod paleocoenoses suggest cold and xeromorphic habitats between } 25,500 \text { and } \\
14,000 \text { years BP. }\end{array}$ \\
\hline $\begin{array}{l}\text { 19. Mkh4.3-S3, } \\
36.3 \mathrm{~m}\end{array}$ & $\begin{array}{l}\text { black-colored } \\
\text { peat }\end{array}$ & ca. 12,200 & $\begin{array}{l}\text { Few remains of an eurybiotic and a calceophile species. Highly dispersed organic } \\
\text { matter and its black color probably indicate mineralization of organic matter under } \\
\text { conditions of mesotrophic bogs. These processes seem to be responsible for the } \\
\text { destruction of the fossil testate amoebae, as that occurs in present-day mesotrophic } \\
\text { bogs. }\end{array}$ \\
\hline $\begin{array}{l}\text { 20. Mkh4.3-S4, } \\
\quad 36.4 \mathrm{~m}\end{array}$ & $\begin{array}{l}\text { brown-colored } \\
\text { peat }\end{array}$ & $12,020 \pm 205$ & $\begin{array}{l}\text { Low temperatures and relatively high humidity might cause low species diversity in } \\
\text { the sample. The latter is indicated by the presence of hydro- and sphagnophiles such } \\
\text { as Centropyxis aculeata and Heleopera petricola. For these species, the optimum } \\
\text { level of ground water in oligotrophic bogs of southern taiga areas varies from } 7 \text { to } 22 \\
\mathrm{~cm} \text { (Bobrov et al., 1999). }\end{array}$ \\
\hline $\begin{array}{l}\text { 21. Mkh99-S1, } \\
37.6 \mathrm{~m}\end{array}$ & peaty soil & $7520 \pm 50$ & Few rhizopod species, indicating a wet habitat. \\
\hline $\begin{array}{l}22-31 . \text { Mkh- } 6.2 \\
\text { profile }\end{array}$ & peat & ca. $3000-2800$ & $\begin{array}{l}\text { Peat accumulated on the bottom of a large thermokarst depression (Fig. 3). The } \\
\text { sediments were later cryoturbated. }\end{array}$ \\
\hline $\begin{array}{l}\text { 22. } \mathrm{S} 1 \text {, } \\
0.5-0.8 \mathrm{~m}\end{array}$ & & $2925 \pm 30$ & No rhizopod shells. \\
\hline $\begin{array}{l}\text { 23. S6, } \\
2.1-2.2 \mathrm{~m}\end{array}$ & & $2885 \pm 30$ & $\begin{array}{l}11 \text { taxa, mostly hygro- and hydrophilic species of the Centropyxis and Difflugia } \\
\text { genera, reflecting wet habitat, probably an open body of water. }\end{array}$ \\
\hline $\begin{array}{l}\text { 24. S8, } \\
\qquad 2.2-2.3 \mathrm{~m}\end{array}$ & & $2980 \pm 35$ & $\begin{array}{l}17 \text { species and intraspecific taxa. Numerous remains of the mesotrophic-eutrophic } \\
\text { Cyphoderia sp., the calceophilic Centropyxis plagiostoma and } 6 \text { species from the } \\
\text { Difflugia genus indicate a mesotrophic habitat. }\end{array}$ \\
\hline $\begin{array}{l}\text { 25. S11, } \\
2.4-2.5 \mathrm{~m}\end{array}$ & & & $\begin{array}{l}\text { Numerous remains of } 18 \text { species and intraspecific taxa that lived in a mesotrophic, } \\
\text { hydromorphic habitat. }\end{array}$ \\
\hline $\begin{array}{l}\text { 26. } \mathrm{S} 12 \\
2.5-2.55 \mathrm{~m}\end{array}$ & & $2740 \pm 35$ & No rhizopod shells. \\
\hline $\begin{array}{l}\text { 27. } \mathrm{S} 14 \text {, } \\
\quad 2.6-2.65 \mathrm{~m}\end{array}$ & & & $\begin{array}{l}13 \text { taxa, mostly sphagnobiotic and sphagnophilic species, characteristic of } \\
\text { meso-oligotrophic stage of bog formation. Dominant complex includes Difflugia } \\
\text { globulosa and } D \text {. globulus. The first occurs in Sphagnum-raising bogs with } \\
\text { temporary water bodies (Meisterfeld, 1977). }\end{array}$ \\
\hline $\begin{array}{l}\text { 28. S15, } \\
\begin{array}{l}2.65-2.7 \mathrm{~m} \\
\text { 29. } \mathrm{S} 16 \\
2.7-2.8 \mathrm{~m}\end{array}\end{array}$ & & & $\begin{array}{l}15 \text { eurytopic intraspecific taxa characteristic of a wet habitat. Enhanced } \\
\text { hydromorphism is indicated by the presence of hydrophilic Difflugia species. } \\
13 \text { species and intraspecific taxa typical of the meso-oligotrophic stage of bog } \\
\text { formation and for mesotrophic, hydromorphic habitats. }\end{array}$ \\
\hline
\end{tabular}


Table 2 (continued)

\begin{tabular}{|c|c|c|c|}
\hline $\begin{array}{l}\text { Sample ID, } \\
\text { elevation (a.s.l) }\end{array}$ & $\begin{array}{l}\text { Type of } \\
\text { sediment }\end{array}$ & $\begin{array}{l}\text { Age, }{ }^{14} \mathrm{C} \\
\text { years BP }\end{array}$ & Rhizopod assemblages and their ecological interpretation \\
\hline $\begin{array}{l}\text { 30. S17, } \\
2.75-2.8 \mathrm{~m}\end{array}$ & & $3020 \pm 70$ & No rhizopod shells. \\
\hline $\begin{array}{l}\text { 31. S18, } \\
\quad 2.8-2.85 \mathrm{~m}\end{array}$ & & & $\begin{array}{l}9 \text { taxa representing eurytopic and hydrophilic groups, characteristic of } \\
\text { meso-oligotrophic and oligotrophic conditions with slightly acidic pH. Presence of } \\
\text { typical hydrophiles (Difflugia globulus and D. globularis) indicates a hydromorphic } \\
\text { stage of bog formation. }\end{array}$ \\
\hline 32. $\mathrm{S} 19,2.9 \mathrm{~m}$ & & modern & $\begin{array}{l}13 \text { taxa, mainly eurytopic, occurring both in soils and lake environment. Presence of } \\
\text { hydrophilic species (e.g. Centropyxis ecornis) reflects oligo-mesotrophic and } \\
\text { mesotrophic conditions with pH close to neutral. This is supported by the presence of } \\
\text { the dominant complex Difflugia globulus (occurring mainly at the lake and lake-bog } \\
\text { transition stages) and the presence of calceophilic Centropyxis plagiostoma. }\end{array}$ \\
\hline $\begin{array}{l}33-42 . \text { Mkh-1.6.1 } \\
\text { profile }\end{array}$ & peat & & Peat was formed in a small thermokarst depression (Fig. 3). \\
\hline 33. S2, $17.2 \mathrm{~m}$ & & $1080 \pm 35$ & $\begin{array}{l}\text { Rhizopod assemblage ( } 28 \text { species and intraspecific forms) is characteristic of forested } \\
\text { habitats. Eurybiotic Centropyxis constricta and calceophilic C. plagiostoma } \\
\text { dominate. Sphagnobiotic species are also numerous. }\end{array}$ \\
\hline $\begin{array}{r}34-38 . \mathrm{S} 3-\mathrm{S} 9 \\
17.3-17.9 \mathrm{~m}\end{array}$ & & $\begin{array}{l}\text { from } 1240 \pm 60 \\
\text { to } 1105 \pm 35\end{array}$ & No rhizopod shells. \\
\hline $\begin{array}{l}\text { 39. S10, } \\
18.05 \mathrm{~m}\end{array}$ & & $1360 \pm 35$ & $\begin{array}{l}28 \text { species, varieties and forms of various testaceans. Xerophilic species of } \\
\text { Valkanovia, Assulina, Corythion, and Nebela representing a coarse-humus } \\
\text { sphagnophilic group; Centropyxis complex and C. plagiostoma, representing a } \\
\text { mesotrophic habitat group; and C. elongata, C. platystoma and Difflugia decloitrei, } \\
\text { representing a hygrophilic group. Rhizopod assemblage is likely to reflect an } \\
\text { alternating water supply during the growing season, which probably ranged from } \\
\text { extremely wet to temporary xeromorphic conditions. }\end{array}$ \\
\hline $\begin{array}{l}\text { 40. S13, } \\
\quad 18.35 \mathrm{~m}\end{array}$ & $\begin{array}{l}\text { base of active } \\
\text { layer }\end{array}$ & & $\begin{array}{l}18 \text { species and intraspecific taxa, representing sphagnophilic Arcella, Valkanovia, } \\
\text { Nebela species and hydrophilic Difflugia species. Assemblage is typical of } \\
\text { oligotrophic bogs with near-surface water table. }\end{array}$ \\
\hline $\begin{array}{l}\text { 41. S14, } \\
\quad 18.45 \mathrm{~m}\end{array}$ & active layer & & $\begin{array}{l}12 \text { taxa represent a hygro- (Arcella and Centropyxis) and hydrophilic (Difflugia) } \\
\text { complex, typical of bog formation stage with conditions more oligotrophic (likely } \\
\text { with open bodies of water) than for most other studied paleocoenoses, as only } \\
\text { calceophilic C. plagiostoma is present. }\end{array}$ \\
\hline $\begin{array}{l}\text { 42. S } 15, \\
18.55 \mathrm{~m}\end{array}$ & modern soil & & $\begin{array}{l}16 \text { taxa are characteristic of an excessively wet and oligotrophic habitat. Numerous } \\
\text { hydrophilic Difflugia species may reflect a temporary open body of water. }\end{array}$ \\
\hline $\begin{array}{l}\text { 43. Mkh1.7.2-S4, } \\
10.6 \mathrm{~m}\end{array}$ & sandy soil & $1400 \pm 60$ & $\begin{array}{l}26 \text { species and intraspecific taxa, mostly eurybiotic. Presence of hydrophilic Difflugia } \\
\text { species and calceophilic Centropyxis plagiostoma suggests peaty soil with a slightly } \\
\text { acidic } \mathrm{pH} \text {. }\end{array}$ \\
\hline 44. TKS-S1 & recent lake & & $\begin{array}{l}\text { Low number of species and low abundance of testa. Single finding of the calceophilic } \\
\text { Centropyxis plagiostoma suggests a slightly acidic } \mathrm{pH} \text {. }\end{array}$ \\
\hline
\end{tabular}

B - an exposure, $6.7 \mathrm{~km}$ south of Cape Bykovsky (see Fig. 2); Mkh—Mamontovy Khayata section.

this study to ordinate the past environmental trends. The cluster analysis of testate amoebae assemblages has been used to better differentiate Late Pleistocene and Holocene rhizopod assemblages.

\section{Results and discussion}

Total of 96 samples from modern soils, Holocene and Late Pleistocene sediments were investigated. No testate amoebae were found in 48 samples, 10 samples contained only singular shells of testate amoebae and/ or their fragments. Eighty-six species, varieties and forms of testate amoebae were found in the 38 Pleistocene and Holocene samples (Table 1). The rhizopod assemblages and their paleoecological interpretations are presented chronologically in Table 2 and Fig. 3, beginning from the oldest. Some pedochemistry characteristics of the sediments studied are presented in Table 3. 


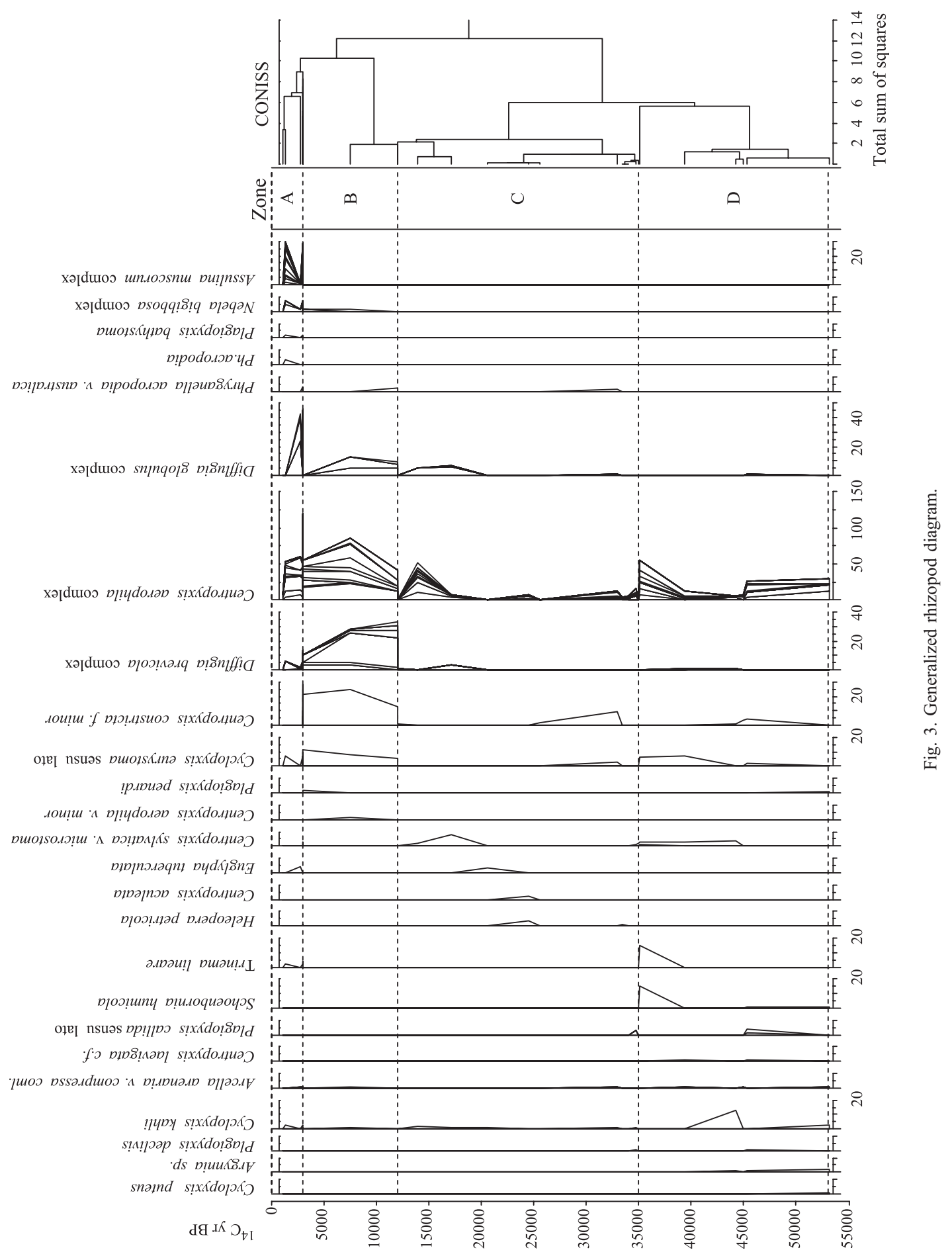


Table 3

Pedochemistry characteristics of analyzed samples

\begin{tabular}{|c|c|c|c|c|c|c|c|}
\hline No. & Sample ID & Type of sediment & $\mathrm{m}$ (a.s.1.) & $\mathrm{pH}\left(\mathrm{CaCl}_{2}\right)$ & Carbonate (wt.\%) & $\mathrm{C} / \mathrm{N}$ & TOC (wt.\%) \\
\hline 1 & B-S7 & peat inclusion & 10.5 & 6.57 & 0.60 & 12.42 & 9.33 \\
\hline 2 & MKhK1-S5 & peaty soil & 10.5 & 7.38 & 3.85 & 12.93 & 2.11 \\
\hline 3 & MKhKB2-S2 & soil & 14.8 & 6.36 & 1.29 & 12.09 & 9.43 \\
\hline 6 & MKhKB3-S1 & peat & 15 & 7.58 & 2.46 & 9.53 & 2.93 \\
\hline 7 & MKhKB4-S2 & silty soil & 14.9 & 5.77 & 1.26 & 12.90 & 12.31 \\
\hline 8 & MKhKB8-S3 & soil & 18.5 & 7.35 & 1.41 & 12.44 & 7.08 \\
\hline 10 & MKhKB6-S10 & silty soil & 19.6 & 7.45 & 1.50 & 13.69 & 7.27 \\
\hline 11 & MKhKB7-S2 & silty soil & 20.65 & 6.97 & 1.03 & 12.22 & 8.73 \\
\hline 12 & MKhKB7-S3 & peaty soil & 20.7 & 6.69 & 1.90 & 16.16 & 12.39 \\
\hline 19 & MKh4.3-S3 & black peat & 36.3 & 5.18 & 0.58 & 16.41 & 12.48 \\
\hline 20 & MKh4.3-S4 & brownish peat & 36.4 & 4.74 & 1.67 & 19.99 & 27.02 \\
\hline 22 & MKh6.2.-S1 & sand & 0.745 & 7.26 & 0.70 & 7.67 & 0.96 \\
\hline 25 & MKh6.2.-S11 & peat & 2.375 & 4.50 & & 15.93 & 9.81 \\
\hline 26 & MKh6.2.-S12 & peat & 2.525 & 4.63 & & 14.02 & 8.63 \\
\hline 31 & MKh6.2.-S18 & peat & 2.825 & 5.45 & & 12.44 & 5.77 \\
\hline 32 & MKh6.2.-S19 & peat & 2.875 & 6.13 & & 12.99 & 4.80 \\
\hline 33 & MKh1.6.1.-S2 & peat & 17.3 & 4.10 & 0.80 & 13.68 & 6.14 \\
\hline 36 & MKh1.6.1.-S13 & peat & 18.35 & 3.90 & & 15.14 & 12.62 \\
\hline 37 & MKh1.6.1.-S14 & peat & 18.45 & 3.81 & & 16.25 & 18.61 \\
\hline 38 & MKh1.6.1.-S15 & peat & 18.55 & 3.96 & & 14.61 & 15.90 \\
\hline 39 & MKh1.7.2.-S4 & sandy soil & 10.6 & 5.26 & 0.16 & 13.66 & 11.09 \\
\hline
\end{tabular}

\subsection{Species diversity}

The number of rhizopod species in the samples varied between 2 and 28 (Fig. 4A). Generally, the species number in the Holocene samples is higher than in the Pleistocene ones. The highest species diversity is in the late Holocene samples (up to 28 species and infraspecific taxa), although it was rather high (up to 15) in the Pleistocene samples dated to $53,020+2670 /-2000$ (\#1 in the Table 2), 44,280+ 1320/ - 1130 (\#3), and ca. 35,000 years BP (\#7). As the diversity of species depends not only on ecological conditions, but on climate as well, it may be suggested that the environmental conditions of the paleocoenosis with higher rhizopod diversity were the most climatically favorable. In other words, the more severe the climate was, the lower the diversity of habitats and species.

\subsection{Ecological groups}

The recovered rhizopods may be classified into four groups (Fig. 4B) with similar ecological preferences: (1) aquatic (hygro- and hydrophilic) species; (2) calceophilic species, namely Centropyxis plagios- toma with its three forms differing in body size; (3) eurybiotic and soil species; and (4) sphagnophilic species. A special significance was assigned to $C$. plagiostoma as the species occurred most frequently in all sediments studied.

Aquatic species are present in the samples, dated from 53,000 to $35,000(\# 1-7), 33,450+260 /-250$ years BP (\#12), and in the Holocene samples (\#21-44). Sphagnophilic species were found in the same samples as aquatic species, but they were not found in the samples, dated to $>44,980$ (\#4), 35,050+390/ -370 $(\# 8)$, and 33,450+269/-250 (\#12) years BP, where hydrophilic species are present. The calceophilic $C$. plagiostoma is present in more than $80 \%$ of the samples (Fig. 4). However, it was not found in samples with low rhizopod density and low species diversity. Eurybiotic and soil species form a complex typical for humusaccumulating soil horizons in the samples, dated to $53,020+2670 /-2000$ (\#1), 45,300+1200/ - 1050 (\#2), and 44,280+1320/-1130 (\#3) years BP. Few remains of eurybiotic and soil species were also found in the samples dated to ca. 35,000 (\#7), 20,000 (\#17), and 12,000 (\#19) years BP. Some eurytopic and soil species were found in the Holocene samples, dated to $1360-1000(\# 33-36)$ years 
A

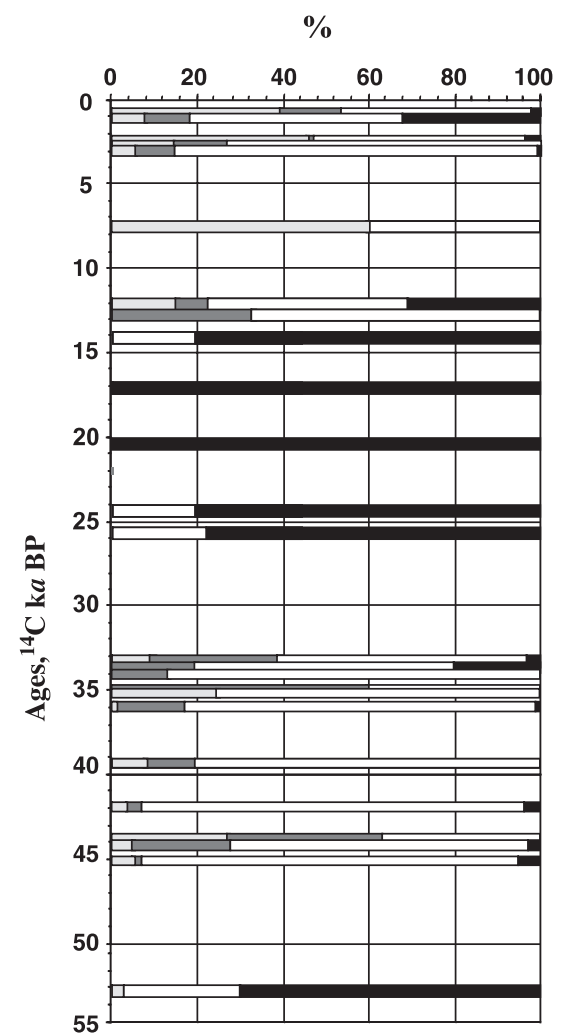

B

Number of taxa

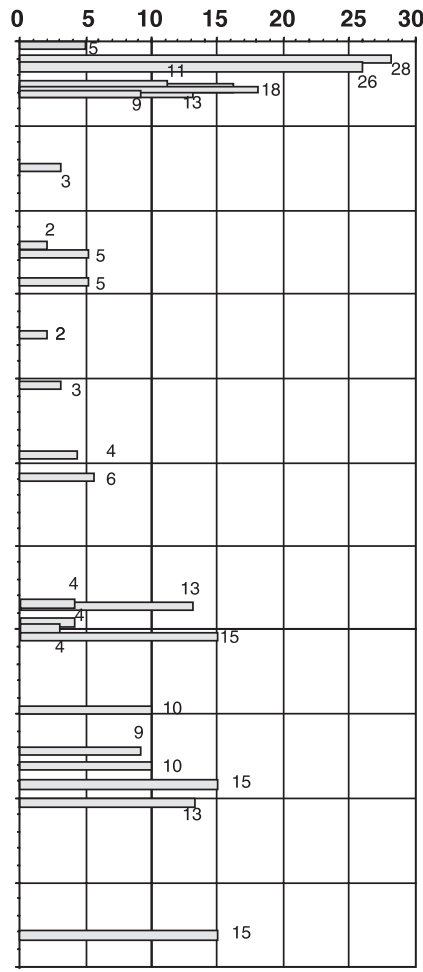

$\square$ Group H $\square$ Group C $\square$ Group E $\square$ Group S

Fig. 4. (A) Structure of ecological groups of rhizopods in Pleistocene and Holocene habitats: H-hygro- and hydrophilic species; Ccalceophilic species C. plagiostoma (three size groups); E- eurybiotic and soils species; S—sphagnophilic species. (B) Species diversity in the Holocene and Late Pleistocene samples.

BP. One species from this group, Plagiopyxis bathystoma, is known as a species characteristic for the early stages of paludification in the taiga forest soils (Bobrov, unpublished).

\subsection{Dominant complex of rhizopods}

The dominant complex (with a frequency of more than $30 \%$ ) comprises mostly eurybiotic species (Fig. 5), especially Centropyxis aerophila, which is dominant in the majority of high-latitude habitats (Beyens et al., 1986). In addition to the typical Arctic species, some species (e.g. C. plagiostoma, Centropyxis platystoma, Cyclopyxis kahli) that are typical for the modern soils of lower latitudes were found. The dominant complex is also characterized by the presence of a large number of hygro- and hydrophilic Centropyxis and Difflugia species. This is an important indication of hydromorphic conditions in paleocoenoses with high species diversity.

Generally, the dominant complexes of the Late Pleistocene and Holocene rhizopod assemblages are very similar as all Late Pleistocene dominant species are also represented in the Holocene dominant complex. These common species consist of a taxonomic majority of the testate amoebas found in the Bykovsky Peninsula deposits. Partly, they include eurybiotic species (e.g. C. aerophila, Centropyxis sylvatica, Cyclopyxis eurystoma v. parvula), but also some indicator species. For example, C. plagiostoma, a 


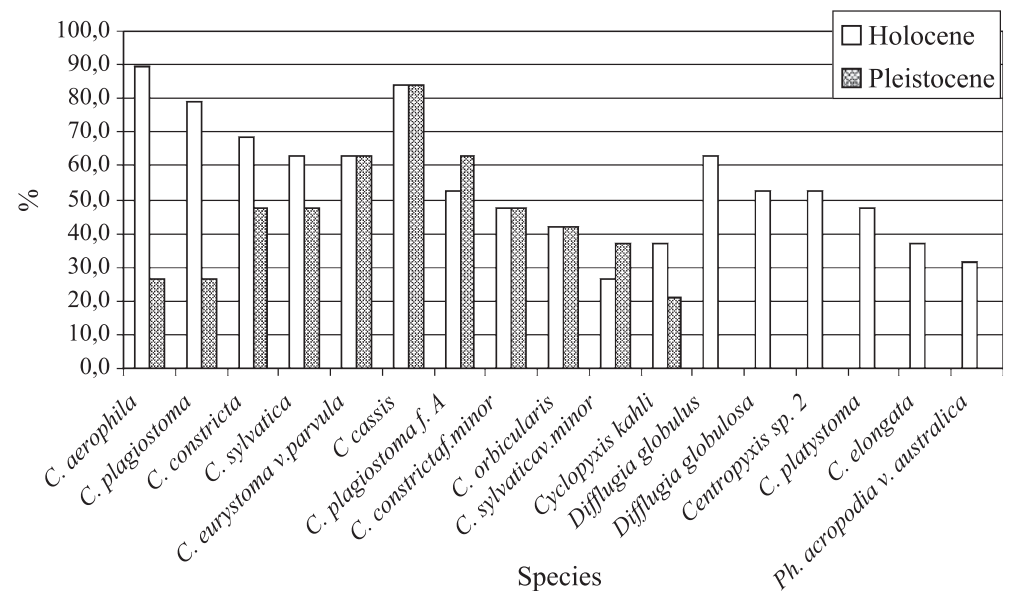

Fig. 5. Ranking of dominant complex's species of testate amoebae from Holocene and Pleistocene habitats by their frequency in the samples.

frequently found calceophile, is an indicator of slightly acidic soils in most of the Late Pleistocene/Holocene habitats. Centropyxis cassis, a species characteristic for the aquatic moss group (Chardez, 1965), was found in $80 \%$ of the samples, indicating that the majority of habitats, where rhizopods were found, had an excessive water content during deposit formation. It is also very notable that this hydrophilic species is absent in the deposits dated from 25,000 to 14,000 years PB.

\subsection{Indicator species}

The sphagnophilic Nebela species occurred in Holocene peat from the thermokarst depression, dated ca. 3000-2800 (\#22-31) years BP, while other sphagnophiles (Assulina muscorum, Valkanovia elegans) were found only in the peat dated from $1360 \pm 35$ (\#35) to $1080 \pm 35$ (\#33) years BP.

The level of nutrient input in most biotopes had not been oligotrophic, but closer to mesotrophic, as reflected by numerous calceophilic C. plagiostoma shells. This may explain why typical sphagnophilic species are rare in the sediments. Hygro- and hydrophilic Arcella arenaria, Difflugia globulus, Difflugia globulosa, Difflugia minuta, Difflugia oblonga, Centropyxis ecornis, Centropyxis elongata, C. platystoma are present mainly in the Holocene samples, where they often dominate, but they are rare in the Pleistocene samples. On the contrary, in the latter samples, typical soil species such as Plagiopyxis declivis and Schoenbornia humicola were found.

\subsection{Polymorphic species}

Some eurybiotic species were found in different size forms such as typica, grandis, minor, and microstoma (Table 1). The most interesting is the calceophilic C. plagiostoma, a well-defined stenobiotic species whose polymorphism in the upper layer of mull soil in Dagestan has been recently analyzed by Foissner and Korganova (1995). They established three size classes for this species, differing in diameter: large $(103 \mu \mathrm{m})$, intermediate $(80 \mu \mathrm{m})$ and small $(57 \mu \mathrm{m})$, which are similar to the typica, major and minor forms in our samples. A morphometric analysis of the shells (Table 4) found in our samples allows us to suggest an adaptive value for such size-related polymorphism of this species. In the Holocene habitats, which were generally wetter than the Pleistocene ones, the typica form occurred more frequently, whereas the forms minor and major were more frequent in the Pleistocene biotopes (Fig. 6). This can be explained by a greater diversity of ecological niches during the Late Pleistocene due to a greater biotope differentiation compared with the Holocene, when peaty soils predominated.

\subsection{Species with a limited geographic distribution}

An Argynnia species was found in the samples, dated to $45,300+1200 /-1050$ (\#2), 44,280+1320/ -1120 (\#3), and $>41,830$ (\#5) years BP. Nowadays, only two species of this 15 species genus, Argynnia 
Table 4

Results of the Kolmogorov-Smirnov test for significance of differences in characters of shell diameter (C. plagiostoma typica, C. plagiostoma f. major, C. plagiostoma f. minor)

\begin{tabular}{lllll}
\hline $\begin{array}{l}\text { Size forms of Centropyxis } \\
\text { plagiostoma }\end{array}$ & No. & $\begin{array}{l}\text { Mean, } \\
\mu \mathrm{m}\end{array}$ & $V$ & $P$ \\
\hline typica & 30 & 74.9 & 9.2 & $<0.001$ \\
major & 30 & 99.6 & 6.4 & \\
major & 30 & 99.6 & 6.4 & $<0.001$ \\
minor & 30 & 55.1 & 8.0 & \\
typica & 30 & 74.9 & 9.2 & $<0.001$ \\
minor & 30 & 55.1 & 8.0 &
\end{tabular}

$V$-coefficient of variation; $P$-significance level of preference of distributions.

dentistoma and Argynnia vitrea have cosmopolitan or broad distributions (Ogden and Hedley, 1980), whereas others are restricted to narrowly defined regions in Canada, Eurasia, Australia, and the Antarctic (Deflandre, 1936; Meisterfeld, 1998). All Argynnia species inhabit Sphagnum bogs and acidic humus within the forest zone and only A. dentistoma has been found in the Arctic biotopes (Beyens and Chardez, 1995). This fact provides additional evidence for the existence of a unique environment in the area during the Late Pleistocene. The finding of Cyclopyxis puteus in the sample dated ca. 45,000 (\#2) years BP also supports this conclusion. The modern northern distribution limit of this species was previously noticed in soils of Devon Island (Canada) and Spitsbergen (Beyens and Chardez, 1995); in soils of Bering Island, the coniferous rain forests of British Columbia, and in the sprucedominated southern taiga (Bobrov, unpublished).

It is also interesting to note the findings of sphagnophilic Nebela bigibbosa in the late Holocene sam-

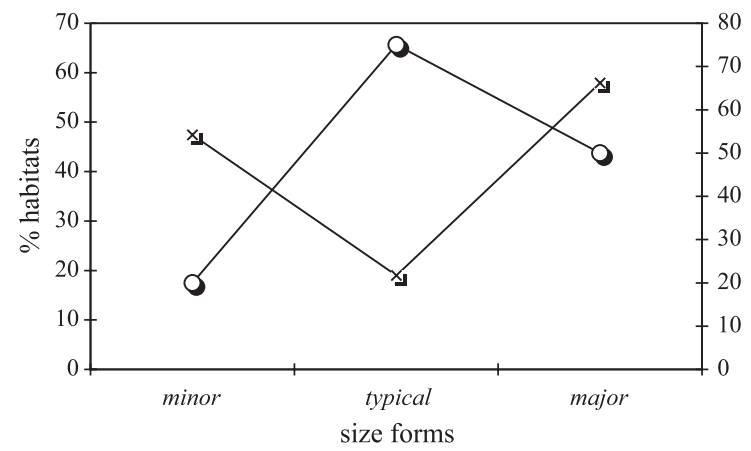

Fig. 6. Frequency (\%) of different size forms C. plagiostoma in Pleistocene and Holocene habitats; $\times$-Pleistocene, $\mathrm{O}-$ Holocene. ples dated to $1360 \pm 35$ (\#35) and $1080 \pm 35(\# 33)$ years BP. Previously, this species has only been found as far north on Spitsbergen (Penard, 1903).

\subsection{Detrended correspondent analysis}

The ordination presented in Fig. 7 reflects a response of testate amoebas to past environmental trends. Axis 1 is most closely related to water table and soil moisture, while Axis 2 is more closely related to $\mathrm{pH}$ of the soil moisture. This means that the ordination of the Late Pleistocene and Holocene microhabitats mostly depended upon the differences in composition of ecological and morphological groups of testate amoebae. In four-measuring ecological space for the different factors we have used the following values: Axis 1 (0.43); Axis 2 (0.28); Axis 3 (0.26); Axis 4 (0.16). The value is rather high for Axis 1 (hydrological condition), and Axes 2, 3 and 4 show weaker gradients of a difference in the data. The significance of $\mathrm{pH}$ for the Late Pleistocene samples was less significant-all samples are in a rather narrow interval (Fig. 7). For the Holocene samples this influence was stronger, from 0 up to 3.1, apparently due to the presence of peat with acid $\mathrm{pH}$ (Table 3). Thus, detrended correspondence analysis shows essential differences between the Late Pleistocene and Holocene samples. The transition zone is caused by similar ecological conditions of a number of habitats during the Pleistocene and Holocene.

\subsection{Grouping of samples by cluster analysis}

The cluster analysis of testate amoebae assemblages also shows the difference between Late Pleisto-

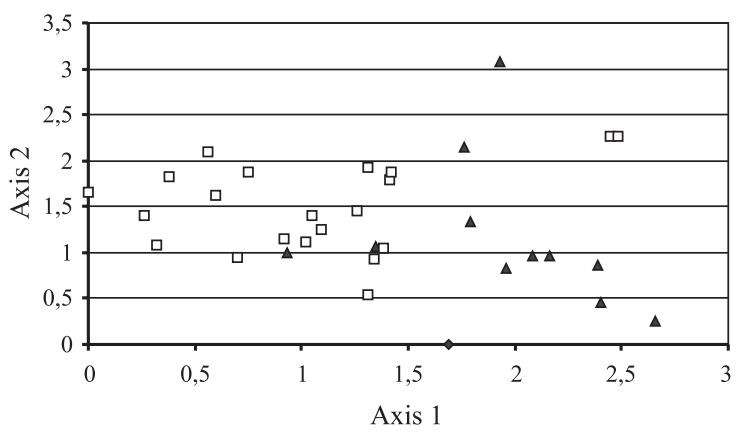

Fig. 7. Results of detrended correspondence analysis (sample scores). 
cene and Holocene rhizopod assemblages (Fig. 3). The species with identical or close microhabitat conditions were combined in the number of complexes (Appendix A). Four main chronostratigrafical zones were distinguished.

Zone D $(53,000-35,000$ years BP) is characterized by dominance edaphic and eurybiotic species from genera Centropyxis, Cyclopyxis, and Plagiopyxis.

Zone C $(35,000-12,000$ years BP) is characteristic by a decrease in species diversity. In the middle and upper part of the zone the presence of hydrophilic species (Heleopera petricola, Centropyxis aculeata, Euglypha tuberculata, and D. globulus) is notable.

Hydrophilic species from Difflugia genus are dominant in zone B $(12,000-3000$ years BP). Their species diversity is the highest in this zone. The hydrophilic species of the Centropyxis genus $(C$. gibba, C. elongata, and C. platystoma) are also very common. Generally, the rhizopods complex of this zone is very characteristic for wet habitats.

Zone A (3000-0 years BP) is characterized by a complex of hydro- and sphagnophilic species from Nebela, Assulina, Valkanovia, Euglypha, and Difflugia genera. Some of these species, (e.g. Corythion dubium) are also common into ro-humus letters and characterize rather xerophilous conditions.

\subsection{Paleoenvironmental reconstructions}

Soil and eurybiotic species typical for hydromorphic mineral soils dominate in the spectrum, dated ca. 53,000 years BP. This reflects a soil environment that is similar to the modern area.

In the buried soils, dated ca. 45,300-43,000 years BP, dominant rhizopods are typical for wet Sphagnum and acid humus locations in the modern tundra. Numerous C. plagiostoma remains indicate the mesotrophic character of nutrition during this period. Temperature conditions were relatively favorable for rhizopods. The diversity of soil and eurybiotic species increased significantly at about 42,000 years BP probably reflecting drier conditions.

During the next stage, 39,300-35,000 years BP, hygro- and hydrophilic species are absent in more than half of the samples, reflecting a drier environment. The species diversity is also rather poor. However, the diversity as well as the structure and complexity of the rhizopods associations increased towards the end of this interval. Generally, it was drier and colder than during the 45,300-43,000 years BP interval. All groups of rhizopods appear in the sample, dated to $33,450+260 /-250(\# 12)$ years BP. This time must have been quite favorable for testate amoebae.

Only a few rhizopod remains were found in the samples dated from 33,400 to 12,200 years BP. A very limited number (from 2 to 6 ) of soil and eurybiotic species (represented only by minor forms) reflects extremely cold and dry conditions.

Hygrophilic, hydrophilic, and sphagnophilic species are absent in the sample dated to ca. 12,200 (\#19) years BP. The soil conditions were still very dry. However, all groups of rhizopods appear in the sample dated to ca. 12,000 (\#20) years BP. Climate conditions became much more favorable for testate amoebae in this later period.

Only hydrophilic and eurybiotic species were observed in the sample dated to 7500 (\#21) years BP. The soil conditions were wet (swampy depression) and probably rather cold.

Late Holocene (ca. 4500-0 years BP) deposits are characterized by the presence of raw-humophilic and sphagnophilic rhizopods, including both xerophilous and hydrophilic species. Mesotrophic rhizopods were also broadly distributed. Generally, all ecological groups of shell amoebae were present during the late Holocene (Fig. 4A). The species composition (Fig. 4B) is also quite varied during that interval, probably reflecting specific features of the highly variable moisture conditions.

\section{Conclusions}

The study shows that rhizopods are an excellent bioindicator proxy for paleoenvironmental reconstructions in the high Arctic. The results obtained are in good agreement with pollen, carpological, entomological and other paleoecological results from the site (Andreev et al., 2002; Schirrmeister et al., 2002b).

Differences between Pleistocene and Holocene environmental conditions are convincingly reflected by rhizopod records. The main characteristic of the fossil rhizopod complexes of Bykovsky Peninsula is the dominance not only eurybiotic species, but also of some stenotopic ones. This may be an important sign of temperature, moisture, and/or nutrient regime dur- 
ing the climate ameliorations. The homogeneous dominant species complex in samples containing the most rhizopods likely reflects similar climatic conditions during these periods.

The differences in species compositions made it possible to determine warmer and colder stages, especially during the Pleistocene. Approximately $42 \%$ of the Pleistocene rhizopod paleocoenoses represent excessively wet habitats (bogs, peaty, and wet soils). The majority of the rhizopod-containing Pleistocene samples represent dry soils. About $80 \%$ of the testacean-containing Holocene samples are currently peaty soils or wet habitats (the biotopes are most favorable for testate amoebae). The presence of testaceans reflects the fact that meso-oligotrophic conditions during sediment formation were more typical of colder and dryer intervals, while oligotrophic conditions were typical during warmer and wetter intervals.

Changes in rhizopod assemblages over 53,000 years were not very dramatic, and mostly concerned rare species and differences in the dominant complexes during the Pleistocene and Holocene. However, these changes were more significant during the Pleistocene than during the Holocene. Probably, they were at least partly responsible for the disappearance of some rarely seen testacean species such as Argynnia sp.

Soil conditions at ca. 53,000 years BP were probably rather similar to the modern day. Temperature conditions were relatively favorable for rhizopods about 45,300-43,000 years BP, but were significantly drier ca. 42,000 years BP. Drier and colder environmental conditions also occurred ca. 39,300-35,000 years BP. Conditions rather favorable for testate amoebae were at about 33,450 years BP. Extremely cold and dry conditions occurred from 33,400 to 12,200 years BP. At the beginning of the Allerød, ca. 12,000 years BP climate conditions were again favorable for testaceans. Rather wet and cold soil conditions have occurred ca. 7500 years BP. A specific feature of the late Holocene (after 4500 years BP) is contrasting moisture conditions in the habitats.

\section{Acknowledgements}

The paper is based on activities, expeditions and analyses, which were mainly supported by the German Ministry of Science in the frame of the
German-Russian cooperation "System Laptev Sea 2000". The authors thank Dr. A.V. Sher for making available the samples collected in 1999. Special thanks are also going to Dr. Nancy Bigelow and 3 anonymous reviewers for their critical and helpful comments on the manuscript.

\section{Appendix A}

List of testate amoebae in the Bykovsky Peninsula deposits. Taxa with similar ecological preferences were grouped into the following ecological complexes:

Arcella arenaria v. compressa complex-A. arenaria $\mathrm{v}$. compressa, $A$. rotundata $\mathrm{v}$. aplanata, $A$. sp. Plagiopyxis callida sensu lato-P. callida, $P$. callida f. grandis.

Centropyxis sylvatica v. microstoma + C. sylvatica v. minuta.

Cyclopyxis eurystoma + C. eurystoma v. parvula. Difflugia brevicola complex-D. brevicola, $D$. ampululla, D. angulostoma, D. decloitrei, D. lacustris, D. litophila, D. mica, D. molesta, D. penardi, D. pristis, D. pulex, D. oblonga, D. oblonga v. longicollis, D. oblonga f. A (160 mkm). Centropyxis aerophila complex-C. aerophila, $C$. aerophila v. grandis, C. aerophila v. sphagnicola, C. cassis, C. cassis v. grandis, C. constricta, $C$. ecornis, C. elongata, C. gibba, C. kolkwitzi f. A (grandis), C. orbicularis, C. plagiostoma sensu lato, C. platystoma, C. sylvatica, C. sylvatica f. A, C. sp. 1, C. sp. 2.

Difflugia difficilis complex-D. difficilis, D. globularis, D. globulosa, D. globulus, D. minuta .

Nebela bigibbosa complex-N. bigibbosa, $N$. lageniformis, $N$. parvula, $N$. tincta.

Assulina muscorum complex-A. muscorum, Valkanovia delicatula, Euglypha anadonta, E. ciliata, E. compressa, E. laevis, E. strigosa, E. sp., Corythion dubium, Trinema complanatum, $T$. enchelys, Pseudodifflugia gracilis.

\section{References}

Andreev, A.A., Schirrmeister, L., Siegert, Ch., Bobrov, A., Demske, D., Seiffert, M., Hubberten, H.-W., 2002. Paleoenvironmental changes in northeastern Siberia during the Quaternary-evi- 
dence from pollen records of the Bykovsky Peninsula. Polarforschung 70, 13-25.

Atlas Arktiki. 1985, GUGK, Moscow. In Russian.

Balik, V., 1994. On the soil testate amoebae fauna (Protozoa: Rhizopoda) on the Spitsbergen Islands (Svalbard). Archiv für Protistenkunde 144, 365-372.

Beyens, L., Chardez, D., 1986. Some new and rare testate amoebae from the Arctic. Acta Protistologica 25 (1), 81-91.

Beyens, L., Chardez, D., 1987. Evidence from testate amoebae for changes in some local hydrological conditions between c. 5000 BP and c. 3800 BP on Edgeoya (Svalbard). Polar Research 5, $165-169$.

Beyens, L., Chardez, D., 1995. An annotated list of testate amoebae observed in the Arctic between the longitudes $27^{\circ} \mathrm{E}$ and $168^{\circ} \mathrm{W}$. Archiv für Protistenkunde 146, 219-233.

Beyens, L., Chardez, D., Landtsheer, R., 1986a. Testate amoebae communities aquatic habitats in the Arctic. Polar Biology 6, 197-205.

Beyens, L., Chardez, D., Landtsheer, R., 1986b. Testate amoebae populations from moss and lichen habitats in the Arctic. Polar Biology 5, 165-173.

Beyens, L., Chardez, D., Baere, D., 1991. Ecology of aquatic testate amoebae in coastal lowlands of Devon Island (Canadian High Arctic). Archiv für Protistenkunde 140, 23-33.

Beyens, L., Chardez, D., Baere, D., 1992. The testate amoebae from the Sondre Strofjord region (West-Greenland): their biogeographic implications. Archiv für Protistenkunde 142, 5-13.

Beyens, L., Chardez, D., Van de Vijver, B., 2000. A contribution to the protist-diversity in the polar regions: testate amoebae date from the Russian Arctic. In: Ceulemans, R., Bogaert, J., Deckmyn, G., Nijs, I. (Eds.), Topics in Ecology. Structure and Function in Plants and Ecosystems. University of Antwerpen, Wilrijk, pp. 101-110.

Bobrov, A.A., 1995. Testate amoebae (Protozoa, Testacea) of Russia and Canada as indicators of climatic changes in Holocene. In: Heikinheimo, P. (Ed.), Proceedings of the SILMU (Finnish Research Programme on Climate Change) International Conference on Past, Present and Future Climate. Held in Helsinki, Finland. Publications of the Academy of Finland, Helsinki, pp. $113-114$.

Bobrov, A.A., 1999. Ekologo-geograficheskie zakonomernosti rasprostraneniya i struktur soobshestv rakovinnykh ameb (Protozoa: Testacea). (Ecological-geographical regularities in distribution and structure of testate amoebae (Protozoa: Testacea) coenoses. Doctor of sciences thesis. Moscow: Moscow State University. In Russian.

Bobrov, A.A., Minaeva, T.Yu., 2000. Indication capacity of testate amoebae (Protozoa: Testacea) and Sphagnum species. In: Rochefort, L., Daigle, J.-Y. (Eds.), Proceedings of the 11th International Peat Congress. Gerry Hood, Quebec, pp. 6-17.

Bobrov, A.A., Charman, D.J., Warner, B.G., 1999. Ecology of testate amoebae (Protozoa: Testacea) on peatlands in Western Russia with special attention to niche separation in closely related taxa. Protist 150, 125-136.

Bonnet, L., 1965. Sur le peuplement thecamoebien de quelques sols du Spitzberg. Bulletin de la Société d'Histoire Naturelle de Toulouse 100, 281-293.
Chardez, D., 1965. Ecologie generale des Thecamoebiens (Rhizopoda, Testacea). Bulletin de l'Institut Agronomigue et des Stations de Recherches Gembloux 3, 306-341.

Chardez, D., Leclercq, J., 1963. Variabilite des populations d'Euglypha strigosa (Ehrbg.) Leidy en fonction de l'habitat. Bulletin de l'Institut Agronomigue et des Stations de Recherches Gembloux 31 (1), 21-27.

Decloitre, L., 1977. Le genre Cyclopyxis (Coplements a jour an 31 decembre 1974, de la Monographie du genre parue en 1929). Archiv für Protistenkunde 119 (1/2), 31-53.

Deflandre, G., 1936. Etude monographie sur le genre Nebela Leidy. Annales de Protistologie 5, 201-322.

Foissner, W., Korganova, G.A., 1995. Redescription of three testate amoebae (Protozoa: Rhizopoda) from a Caucasian soil: Centropyxis plagiostoma Bonnet and Thomas, Cyclopyxis kahli (Deflandre) and C. intermedia Kufferath. Archiv für Protistenkunde 146, 13-28.

Giliarov, M.S., 1955. Soil testate amoebae (Testacea) and their significance for bog soil diagnostics. Pochvovedenie 10, 61-65 (in Russian).

Grospietsch, Th., 1953. Rhizopodenanalitische Untersuchungen an Mooren Ostholstaeins. Archiv für Hydrobiologie 47 (3), $341-452$.

Harnisch, O., 1927. Einige Daten zur rezenten und fossil testacean Rhizopoden-Fauna der Sphagnen. Archiv für Hydrobiologie 18, $246-360$

Harnisch, O., 1948. Rhyzopodenanalyse der Moore. Biologische Zeitblätter 67 (11/12), 551-562.

Heal, O.W., 1963. Morphological variation in certain Testacea (Protozoa: Rhizopoda). Archiv für Protistenkunde 106, 351-368.

Meisterfeld, R., 1977. Die horizontale und vertikale Verteilung der Testaceen (Rhizopoden Testacea) in Sphagnum. Archiv für Hydrobiologie 79, 319-356.

Meisterfeld, R., 1998. First records of testate amoebae (Protozoa: Rhizopoda) from Mount Buffalo National Park, Victoria: preliminary notes. Victorian Naturalist 115 (5), 231-238.

Ogden, C., Hedley, R.H., 1980. An Atlas of Freshwater Testate Amoebae. Oxford Univ. Press, Oxford.

Opravilova, V., 1989. Some information on testate amoebae from Spitsbergen. Fauna Norvegica. Serie A 10, 33-37.

Penard, E., 1903. Notice sur les Rhizopodes du Spitzbergen. Archiv für Protistenkunde 2, 238-282.

Sandon, H., 1924. Some Protozoa from the soils and moss of Spitzbergen. Journal of the Linnean Society of Zoology 27, 449-475.

Schirrmeister, L., Kunitsky, V.V., Grosse, G., Kuznetsova, T., Kuzmina, S., Bolshiyanov, D., 2001. Late Quaternary and recent environmental situation around the Olenyok Channel (western Lena Delta) and Bykovsky Peninsula. Reports on Polar and Marine Research 388, 85-134.

Schirrmeister, L., Siegert, C., Kunitsky, V.V., Grootes, P.M., Erlenkeuser, H., 2002a. Late Quaternary ice-rich permafrost sequences as a paleoenvironmental archive for the Laptev Sea Region in Northern Siberia. International Journal Earth Science 91, $154-167$.

Schirrmeister, L., Siegert, C., Kuznetsova, T., Kuzmina, S., Andreev, A.A., Kienast, F., Meyer, H., Bobrov, A.A., 2002 b. 
Paleoenvironmental and paleoclimatic records from permafrost deposits in the Arctic region of Northern Siberia. Quaternary International 89, 97-118.

Schönborn, W., 1962. Die Ökologie der Testaceen im oligotrophen Seen, dargestellt am Biespiel des Grosse Stechlisees, Limnologica (Berlin), 1(2), 111-182.

Schönborn, W., 1966. Beitrag zur Ökologie und Systematik der Testaceen Spitzbergens. Limnologica (Berlin) 4, 463-470.

Scourfield, D.J., 1897. Contributions to the non-marine fauna of Spitzbergen: I. Preliminary note and reports on the Rhizopoda. Proceedings of the Zoological Society of London 45, 784-792.

Sher, A.V., 1997a. Environmental restructuring at the Pleistocene/ Holocene boundary in the East Siberian Arctic and its role in mammalian extinction and establishment of modern ecosystems (Communication 1). Kriosfera Zemli 1, 21-29 (in Russian).

Sher, A.V., 1997b. Environmental restructuring at the Pleistocene/ Holocene boundary in the East Siberian Arctic and its role in mammalian extinction and establishment of modern ecosystems (Communication 2). Kriosfera Zemli 2, 3-11 (in Russian).

Sher, A., Parmuzin, I., Bortsov, A., 2000. Ice complex on Bykovsky Peninsula. Reports on Polar and Marine Research 354, 169-186.

Siegert, C., Schirrmeister, L., Kunitsky, V., Sher, A.V., 1999. Paleoclimate signals of the ice-rich permafrost. Geological-geomorphological characteristics of the study area. Reports on Polar and Marine Research 315, 145-152.
Siegert, C., Schirrmeister, L., Babiy, O.A., 2002. The sedimentological, mineralogical and geochemical composition of Late Pleistocene permafrost deposits of the Bykovsky Peninsula, Northern Siberia. Polarforschuing 70, 3-11.

Smith, H.G., 1987. A species-poor testate rhizopod fauna on Brabant Island. British Antarctic Survey Bulletin 77, 173-176.

Smith, H.G., 1988. Influence of temperature on test morphology of natural populations of testate rhizopods in the maritime Antarctic. IX Protozoological Congresse, Berlin, p. 120.

Tolonen, K., 1986. Rhizopod analysis. In: Berglund, B.E. (Ed.), Handbook of Holocene Palaeoecology and Palaeohydrology. Wiley, Chichester, pp. 645-666.

Trappeniers, K.K., Chardez, D., Nijls, I., Beyens, L., 2002. Testacea amoebae assemblages from soils in the Zackenberg area, northeast Greenland. Arctic, Antarctic, and Alpine Research 34, 94-101.

Yanin, B.T., 1983. Osnovy Tafonomii (Principles of Taphonomy) Nedra, Moscow. In Russian.

Yurtsev, B.A., 1966. Gipoarkticheskiy botaniko-geografichesky poyas i proiskhozhdenie ego flory (Hypoarctic botanical-geographical belt and origin of its flora) Nauka, Moscow-Leningrad. In Russian.

Yurtsev, B.A., 1981. Reliktovye stepnye complexly Severo-Vostochnoy Azii (Relic steppe complexes of Northern Eurasia) Nauka, Novosibirsk. In Russian. 